\title{
Voices of Migrants: Rural-Urban Migration in Costa Rica, by Paul Kutsche. Gainesville: University Press of Florida, 1994. xii, 236 pp.
}

\section{Reviewed by James P. Stansbury, Department of Behavioral Science, University of Kentucky.}

Kutsche's book is a welcome addition to recent work on Costa Rica and Central America. The goal of the study is to provide a human face to the often dry statistics on rural-urban migration. The author draws generalizations about migration to San Jose from an analysis of interviews with 14 Costa Ricans. Texts of the interviews with 10 men and four women focus particularly on factors related to their move to San Jose.

The book itself is divided into three sections, the first providing sociocultural and historical context for the study. As the author points out, Costa Rica has a unique colonial legacy. As a peripheral area of the Guatemalan captaincy, the area lacked a military class and large quantities of Native Americans to conquer. It subsequently developed a political culture that maintained the rule of a hereditary elite through the formation of a political class, but eschewed hierarchical distinctions in favor of egalitarian ideology.

Ironically, if the rise of the yeoman farmer in part accounts for Costa Rican uniqueness, it is the beginnings of coffee exportation in the 1830 s that prepared the roots of Costa Rican underdevelopment. More recently, large scale cattle ranching for beef export has brought consolidation of land holdings and the expansion of rural roads, providing a push factor in urban migration (see B.R. DeWalt 1985). Accompanying this has been environmental degradation, a process the author views as a more quiet force leading to the alienation of rural producers.

Migration to San Jose increased dramatically during the 1960s, and the central city grew rapidly during this decade. The 1970s brought growth to the city's concentric rings of aglomeracion, with migration tapering somewhat as a result of the economic crisis of the 1980s. Of interest is the relatively high absorption of migrants into the formal sector of the economy, although recent migrants appear to be less secure than those that arrived in earlier waves. Also of note is the fact that most migrants are women, and that migrants are more likely to be employed than urban natives, perhaps due to a willingness to accept less remunerative or desirable work.

The book's second section, presenting the texts of the interviews, is the most important. These interviews are ably translated and edited. Kutsche has written on male sexual identity and gay life in Costa Rica (e.g. P.Kutsche \& J.B.Page 1991), and this concern shapes the presentation of the interviews and selection of the interviewees. We are early on introduced to a young hustler and other young men who have informed Kutsche's other work. Nevertheless, subsequent interviewees include a political organizer, a teacher, a bootblack, a fireman, an older successful beekeeper and a produce manager. Women migrants included a single-mother who eventually became a government worker and a domestic worker. The material is sufficiently broad, letting the reader feel some of the diversity and commonality among migrants to San Jose. 
The third section presents the author's analysis, providing brief generalizations on the interviews. Perhaps most interesting here are Kutsche's observations regarding increasing psychic costs to migration and the factors predicting migrant success.

The reader of Voices of Migrants will find the author no slave to contemporary theoretical fashion. Absent, perhaps for some blessedly so, are references to intertextuality and exegeses on the finer points of discursivity. As Kutsche notes early on, his inspirations are the life history works of Lewis and Sexton, with methodological predecessors in Kluckhohn and Langness. In a later discussion on informant presentations, he refers to

issues raised by Goffman whereas the discussion of values employs Kluckhohn's quite serviceable definition. Interpretation is straightforward, and discussions of the author's biases and how they may influence both data and interpretation are honest and sensitive.

Nevertheless, Kutsche's critique of Costa Rican popular ideology reflects a concern for denouncing alienating illusion that is quite contemporary, if problematic. The author begins by suggesting that value orientations constitute

\footnotetext{
...what we may label "la leyenda blanca," playing off the "leyenda negra" that Protestant historians saddled Spain with. The leyenda blanca, the myth of Costa Rican idyllic society and culture in the "Switzerland of Central America," persists in the face of careful and uncontroverted historical research...(p.208)
}

Although it is evident that multiple sixteenth and seventeenth-century editions of the Brevsima relación in Holland, Britain, Germany, and France had much to do with the perpetuation of the "black legend," I find it difficult to think of the first bishop of Chiapas as a Protestant historian (see A.Saint-Lu 1991). As for the "white legend" of Costa Rica, the historian A.Perez-Brignoli (1989) is one promoter:

\begin{abstract}
... By studying the case of Costa Rica we can get a feel for possibilities and limitations... The life expectancy is one of Latin America's highest. The degree of control over infectious diseases exceeds all expectations. The electoral process and political life is comparable to the United States or Western Europe. All this is true of an underdeveloped country that finds itself in the middle of a deep economic crisis and which shares in no small measure the misfortunes of the whole region

(1989:180).
\end{abstract}

Perez-Brignoli shares the position with Kutsche that Costa Rica is in no way exempt from the forces of the global economy.

Yet for the historian, Costa Rican uniqueness is less myth than political-economic enigma. Costa Rica not only remained aloof from the "black legend" of the 1980s in Central America, but likewise during earlier epochs of crisis. As an example, PerezBrignoli compares the peaceful resolution of the 1934 banana strike in Costa Rica with the infamous matanza following the Salvadoran insurrection of 1932. As he notes: "ruling class behavior defines a pattern of evolution which will have a decisive effect on the future of Central American societies" (1989:184).

It could well be that the egalitarian and exceptionalist orientations in Costa Rican political culture at once define elite obligations and popular boundaries for action, having very real implications for the conduct of social life. To invoke an earlier proponent of 
interactionism, this is less about false consciousness than an example of how when "....men define situations as real, they are real in their consequences" (W.I.Thomas 1966 [1928]:xl). Familiarity with the outcomes of Central American political violence during the last decade suggests that this may not be such a bad thing.

Despite my reservations about Kutsche's historical and political economic interpretation, his Voices of Migrants is a tremendous contribution to a human understanding of urban migration in Latin America. It is best read for the voices themselves, which are ably presented and intrinsically interesting for anthropologists and students of migration. This book also helps fill the underattended anthropological space south of Mesoamerica and north of the Andes.

\section{References Cited.}

DeWalt, Billie R.

1985 "Microcosmic and Macrocosmic Processes of Agrarian Change in Southern Honduras: The Cattle are Eating the Forest." In Micro and Macro Levels of Analysis in Anthropology: Issues in Theory and Research, B.R. DeWalt \& P.J. Pelto, editors. Pp. 165-186. Boulder: Westview.

Kutsche, Paul, and J. Bryan Page

1991 Male Sexual Identity in Costa Rica, Latin American Anthropology Review. 3:714.

Perez-Brignoli, Hector

1989 [1985] A Brief History of Central America. R.B. Sawrey \& S. Stettri de Sawrey, translators. Berkeley: University of California Press.

Saint-Lu, André

1991 Introducción a Brevísima relación de la destruición de las Indias. Fray Bartolomé de las Casas, 1552. Madrid: Catedra.

Thomas, W.I., editor

1966 [1928] On Social Organization and Social Personality. Pp. vii-lviii. Chicago: University of Chicago Press.

\section{Houses in the Rainforest: Ethnicity and Inequality among Farmers and Foragers in Central Africa, by Roy Richard Grinker; Berkeley and Los Angeles: University of California Press, 1994. xviii, 225 pp.}

\section{Reviewed by Robert Harms, Department of History, Yale University}

Farmers and foragers in Zaire's Ituri forest, we have been told by anthropologists, exist in a symbiotic material relationship by which farmers produce cultivated food and foragers produce forest products. Indeed, the inhabitants of the Ituri themselves echo this assessment. Nevertheless, Roy Richard Grinker argues in this path-breaking book that the 